University of Nebraska - Lincoln

DigitalCommons@University of Nebraska - Lincoln

Faculty Publications from the Harold W. Manter Laboratory of Parasitology

2012

\title{
A New Genus and Species of Lungworm (Nemata: Metastrongyloidea) from Akodon mollis Thomas, 1894 (Rodentia: Cricetidae) in Peru
}

\author{
Maria Elizabeth Morales \\ Universidad Nacional Mayor de San Marcos, helminto_musm@yahoo.com \\ Scott Lyell Gardner \\ University of Nebraska - Lincoln, slg@unl.edu \\ John E. Ubelaker \\ Southern Methodist University, ubelaker@smu.edu
}

Follow this and additional works at: https://digitalcommons.unl.edu/parasitologyfacpubs

Part of the Biodiversity Commons, Parasitology Commons, Terrestrial and Aquatic Ecology Commons, and the Zoology Commons

Morales, Maria Elizabeth; Gardner, Scott Lyell; and Ubelaker, John E., "A New Genus and Species of Lungworm (Nemata: Metastrongyloidea) from Akodon mollis Thomas, 1894 (Rodentia: Cricetidae) in Peru" (2012). Faculty Publications from the Harold W. Manter Laboratory of Parasitology. 762. https://digitalcommons.unl.edu/parasitologyfacpubs/762

This Article is brought to you for free and open access by the Parasitology, Harold W. Manter Laboratory of at DigitalCommons@University of Nebraska - Lincoln. It has been accepted for inclusion in Faculty Publications from the Harold W. Manter Laboratory of Parasitology by an authorized administrator of DigitalCommons@University of Nebraska - Lincoln. 


\title{
A NEW GENUS AND SPECIES OF LUNGWORM (NEMATA: METASTRONGYLOIDEA) FROM AKODON MOLLIS THOMAS, 1894 (RODENTIA: CRICETIDAE) IN PERU
}

\author{
Maria Elizabeth Morales*, John E. Ubelaker†, and Scott L. Gardner $\ddagger$ \\ Department of Protozoología, Helmintología e Invertebrados Afines, Museo de Historia Natural, Universidad Nacional Mayor de San Marcos \\ (MUSM), Apartado 14-0434, Lima, Peru. e-mail: helminto_musm@yahoo.com
}

\begin{abstract}
Akodonema luzsarmientae n.g., n.sp. (Nemata: Metastrongyloidea) is described from the pulmonary arteries and heart from several individuals of "soft grass mouse," Akodon mollis (Rodentia: Cricetidae), collected in the region of Ancash, Peru. The new genus and species is distinguished by a reduction of the dorsal ray to 2 small widely separated papillae.
\end{abstract}

During a study of the helminth parasites of the "soft grass mouse," Akodon mollis Thomas, 1894, from mountain shrub habitat on the western flank of the Andes of Peru, an undescribed species of an angiostrongylid type of nematode representing a new genus was found in the pulmonary arteries and heart. The new species shows some similarity to species of Gallegostrongylus (Mas-Coma, 1977) and Thaistrongylus (Ohbayashi, Kamiya, and Bhaibulaya, 1979) in the reduction, loss, or ancestral absence, of the dorsal ray.

Species of Akodon Meyen, 1833, have a strictly Neotropical distribution, with a northern-most species, Akodon affinis Allen, 1912, occurring in the western part of the Andes in Colombia (Eisenberg, 1989), and many other species distributed over the South American continent to Tierra del Fuego, where the closely related Abothrix hershkovitzi can be found (Patterson et al., 1984). More than 40 species of Akodon have been described (Wilson and Reeder, 2005), and because of cryptic species in the genus, there are probably many more that are currently unrecognized.

Akodon mollis is a small rodent (mean total length $=169.8 \mathrm{~mm}$ ) that inhabits the montane region and Pacific lowlands of northern Peru northward through the central highlands of Ecuador (Patton and Smith, 1992) (Fig. 1). As is typical of species included in Akodon, their diet appears to consist mostly of insects, seeds, and other vegetable material. There are no previous reports of parasites from A. mollis.

\section{MATERIAL AND METHODS}

Between February 1988 and October 1989, 125 specimens of A. mollis were captured using Sherman ${ }^{\mathrm{TM}}$ live traps, from the District of Huayllacayán (lat $10^{\circ} 14^{\prime} 56^{\prime \prime} \mathrm{S}$, long. $77^{\circ} 26^{\prime} 00^{\prime \prime} \mathrm{W}$ ), Province of Bolognesi, Department of Ancash, in the high-altitude puna habitat of the central Andes of Peru (2,100-3,256 m) (Fig. 2).

Specimens of Akodon in this study were captured during a survey of the potential reservoirs of Leishmania spp. by a research group of the Institute of Tropical Medicine "Alexander Von Humboldt" of Cayetano Heredia University in Lima, Peru, from 19 different localities (caserios). After individual mice were sampled for Leishmania spp., they were killed, and the carcasses frozen at $-20 \mathrm{C}$ and deposited in the Department of Mammalogy of the Museo de Historia Natural, Universidad Nacional Mayor de San Marcos (MUSM), in Lima, Peru. Subsequently, individual rodents were thawed and examined for parasites using a binocular dissecting microscope in the Laboratory of Helminthology at MUSM.

Received 22 January 2010; revised 24 November 2011; accepted 5 December 2011.

* Present address: Department of Natural Sciences, New Mexico Highlands University, Las Vegas, New Mexico 87701.

$\dagger$ Department of Biological Sciences, Southern Methodist University, Dallas, Texas 75275 .

\$Harold W. Manter Laboratory of Parasitology, University of Nebraska State Museum, Lincoln, Nebraska 68588-0514.

DOI: 10.1645/JP-GE-2440.1
Nematodes recovered were fixed and stored in $70 \%$ ethanol and later cleared with lactophenol for study.

All nematodes used in this study were deposited in the Colección Helmintológica y de Invertebrados Relacionados del Museo de Historia Natural, MUSM, and in the Parasite Collection of the Harold W. Manter Laboratory of Parasitology, University of Nebraska-Lincoln, Lincoln, Nebraska. Measurements were made with the aid of an ocular micrometer and digital measuring software (Sigma Scan Pro, Systat Software, Inc., Chicago, Illinois). All measurements are given in micrometers except where noted, with the range followed by the mean in parentheses. Drawings were made with the aid of drawing tube attached to a Carl Zeiss light microscope.

\section{DESCRIPTIONS}

\section{Akodonema n. gen.}

Diagnosis: Elongate, delicate nematodes with body of both sexes filiform and tapering to smaller diameter at anterior end. Cuticular sheath absent, cuticle with numerous fine, longitudinal striations. Cephalic region with 3, minute lips, each bearing 2 small papillae. Esophagus claviform in outline, excretory pore well anterior to esophageal-intestinal junction. Intestine filled with blood from host. Both intestine and milky-white uterine tubules spirally arranged within the pseudocoelom.

Male: Tail curved ventrally. Bursa small, incomplete, 2 lateral sides not joined anteriorly or posteriorly. Ventral and lateral rays of bursa long, narrow. Ventral rays fused for most of length, lateral rays equal, arising from common trunk, divided to about $1 / 2$ of length. Dorsal ray absent, but 2 small and delicate papillae present. External dorsal rays present, elongate and narrow. Spicules thin, elongate and well developed. Gubernaculum present.

Female: Oviparous and prodelphic with simple ovejector. Vulva opens at posterior end just anterior to anus, tail short. Eggs elliptical in shape, showing early development of juveniles. Eggs deposited into blood stream, and larvae hatch in lungs of host.

\section{Taxonomic summary}

Etymology: The generic name is an arbitrary combination taken from "Akodo" in reference to the host rodent (Akodon) and the word "nema," which means "thread" in Greek. Gender feminine.

\section{Akodonema luzsarmientae $\mathrm{n} . \mathrm{sp}$. (Figs. 1-7)}

General: Body of both sexes filiform and tapering at anterior end. Cuticle lightly transversely striated. Head smoothly rounded. Mouth with 3 tiny lips. Esophagus club shaped. Excretory pore close to nerve ring. Nerve ring in anterior third of esophagus.

Male (holotype and 9 specimens): Body length 7.8 to $10.6 \mathrm{~mm}$; width at base of esophagus 74 to 87 , maximum width 110 to162. Esophagus 150 to 172 long by 35 to 39 in maximum width. Nerve ring 25 to 28 from anterior end. Excretory pore 19 to 22 from anterior end. Anterior end of testes variable in position, not reaching base of esophagus. Spicules slender, conspicuously striated, equal or subequal, 230 to 246 long by 5 wide; cephalic ends of spicules pointed, edges irregular; distal ends smoothly rounded. Gubernaculum present, poorly cuticularized, 24 to 29 long. Bursa symmetrical and well developed forming two lateral lobes. Dorsa ray reduced to 2 small papillae widely separated. Externodorsal rays long, digitiform, arising separately at base. Lateral rays with common trunk, posterolateral, mediolateral, and externolateral arising from common 


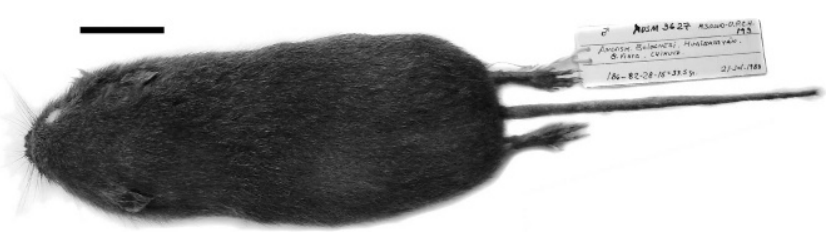

Figure 1. Dorsal view of "soft grass mouse," Akodon mollis Thomas, 1894 (Cricetidae: Sigmodontinae, Akodontini). Scale bar $=5 \mathrm{~cm}$.

trunk, all about equal in size and length. Ventral rays subequal, fused in lower $3 / 4$, ventral trunk widely separate from lateral trunk (Figs. 5, 6).

Female (allotype and 8 other paratype specimens; 9 total females included in the paratype series): Body length 17.5 to 26.9 (21.6) $\mathrm{mm}$ width at base of esophagus 100 to 165 (135), maximum width 240 to 320 (274). Esophagus 132 to 475 long by 114 to 117 . Nerve ring 45 to 172 from anterior end. Excretory pore 57 to 170 from anterior end. Anterior end of ovaries variable in position, but not extending anterior to base of esophagus. Uterine tubules white in life, spirally wound around blood-filled intestine presenting a "barber-pole" appearance common in family. Vulva opening near tip of tail 166 to 174 . Anus 46 to 54 from tip of tail. Phasmidial pores not observed. Tail bluntly rounded. Eggs thin shelled, 75 to 93 long and 112 to 196 wide, laid in pulmonary artery and developing and hatching in lung tissue (Figs. 1-4).

\section{Taxonomic summary}

Type host: Akodon mollis Thomas, 1894, "soft grass mouse" (Cricetidae: Sigmodontinae).

Symbiotypes: Akodon mollis Thomas, 1894, adult males and females, Catalog numbers: 3608, 3611, 3623, 3624, 3628, 3629, 3642, 3643, 3645, $3649,3650,5760,5778,5782,5786,5787,5893$, all deposited in the Mammals Collection at the Museo de Historia Natural, MUSM.

Type locality: District of Huayllacayán $\left(10^{\circ} 14^{\prime} 56^{\prime \prime} \mathrm{S}, 77^{\circ} 26^{\prime} 00^{\prime \prime} \mathrm{W}\right)$, Province of Bolognesi, Department of Ancash, Peru.

Site of infection: Pulmonary artery and branches, heart, and lungs.

Prevalence of infection: Rodents examined, 125 of which 27 were infected $(21.6 \%)$.

Intensity: One to 9 nematodes. Total nematodes recovered, 78 (34 from heart and 44 from lungs).

Type specimens: Holotype male: Colección Helmintológica y de Invertebrados Relacionados, Museo de Historia Natural, MUSMm No. 1699. Allotype female: Colección Helmintológica y de Invertebrados Relacionados, MUSM, No. 1700. Paratypes: Colección Helmintológica y de Invertebrados Relacionados MUSM, Nos. 1701, 1837, 1838, 1839, and Harold W. Manter Laboratory of Parasitology Collection (HWML48041, HWML48042).

Etymology: The specific name honors Dr. Luz Sarmiento, Emeritus Professor of the Universidad Nacional Mayor de San Marcos, Lima, Peru, and founder of the Helminthological Collection at the Natural History Museum, MUSM, in recognition of both her contribution to the knowledge of the Peruvian helminthology and her inspirational teaching for the study of protozoan and other animal parasites.

\section{Remarks}

All members of this group of worms dwell in the tissues of their hosts, often in the blood stream (Spratt, 1961). The new genus, Akodonema, is characterized by having well-developed ventral and lateral rays and with the dorsal ray reduced to a pair of sub-ventral papillae. The spicules are elongate. The morphology of the bursa allows comparisons with Aelurostrongylus Cameron, 1927, Marsupostrongylus Mackerras and Sandars, 1953, Andersonstrongylus Webster, 1978, Thaistrongylus Ohbayashi, Kamiya and Bhaibulaya, 1959, and Gallegostrongylus Mas-Coma, 1977 , all of which have a reduced dorsal ray, or the dorsal ray is deeply divided or absent and/or papillae are present in its place. The new genus is most closely associated with the latter 2 genera. According to Mas-Coma (1977), in Gallegostrongylus, the dorsal ray is deeply divided with each branch of the ray arising separately and distant from each other. The ventral and lateral rays are well developed, and the spicules are short, delicate, and arcuate. As described by Ohbayashi et al. (1979), Thaistrongylus is represented by a single species, Thaistrongylus harinasutai, collected from a single host (Rattus berdmorei Blyth) and described on

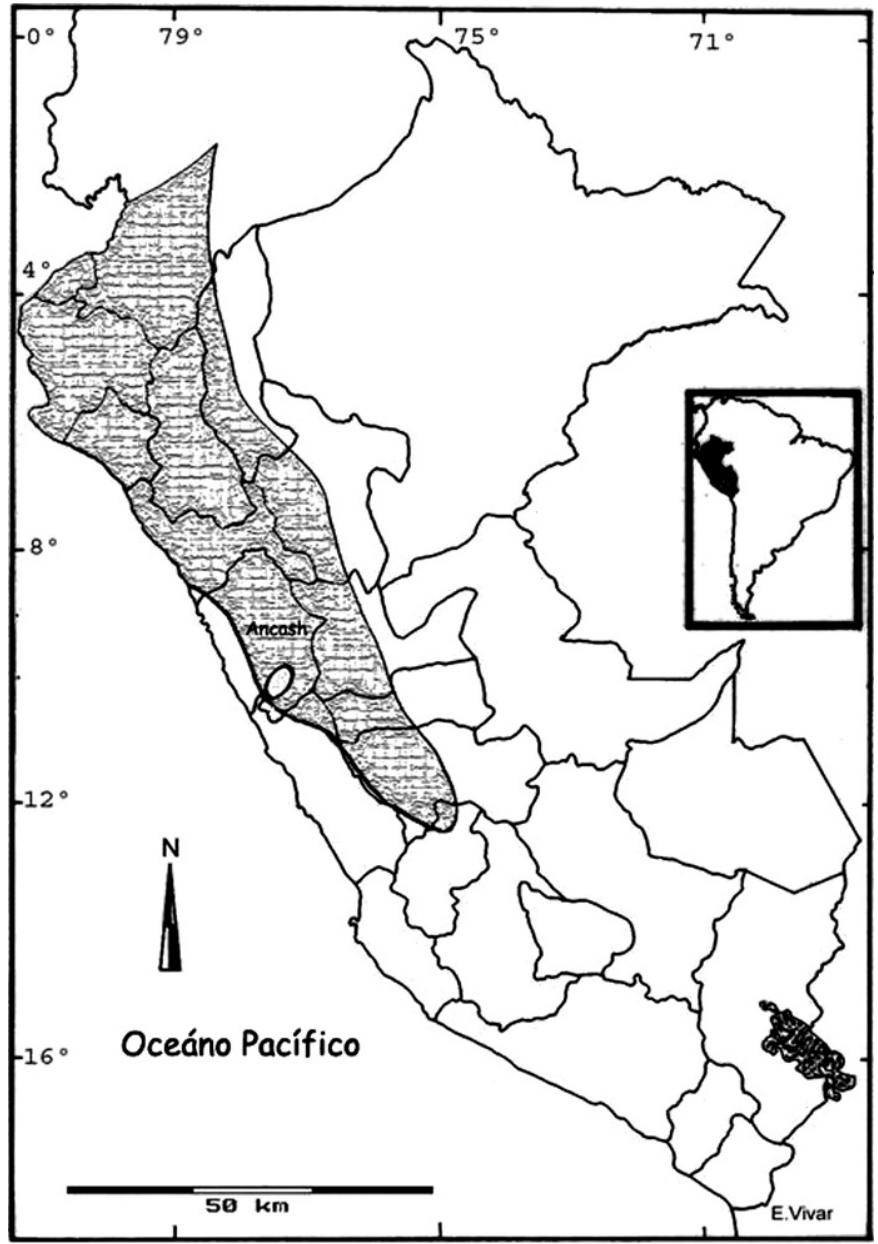

FIgURE 2. Map showing the study area in oval (District of Huayllacayán, Province of Bolognesi, Department of Ancash, Peru) and the distribution of $A$. mollis Thomas, 1894, in Peru (shaded).

the basis of fragmented male and female specimens. The description suggests that the genus has a strongly reduced bursa, including the ventral and lateral rays, and the dorsal ray is reduced to papilla-like and short arcuate spicules. Ubelaker (1986) argued that the genus is very similar to Gallegostrongylus and should be placed in synonymy. The differences between the genera Gallegostrongylus and Thaistrongylus are mainly in how strongly the bursa of the latter is reduced and if the lobes of the dorsal ray are papilla-like or consist of very short rays. On the other hand, Akodonema has ventral and lateral rays strongly developed, similar to either Angiostrongylus or Parastrongylus (see Ubelaker, 1986 for review; see also Robles et al., 2008), and the dorsal ray is clearly reduced to widely separated papillae. The spicules are also of the AngiostrongylusParastrongylus type, being long and thin.

\section{DISCUSSION}

Within the Angiostrongylidae as described by Anderson (1978), 2 groups of genera are evident. A first group is characterized by having intact dorsal rays. This group should remain in the Angiostrongylidae.

\section{REDESCRIPTION}

\section{Angiostrongylidae Anderson, 1978}

Diagnosis: With the characters of the family. Bursa highly developed or reduced, complete, but typical rays always clearly defined. Dorsal ray is present but sometimes divided. Ventral and lateral rays well developed. 

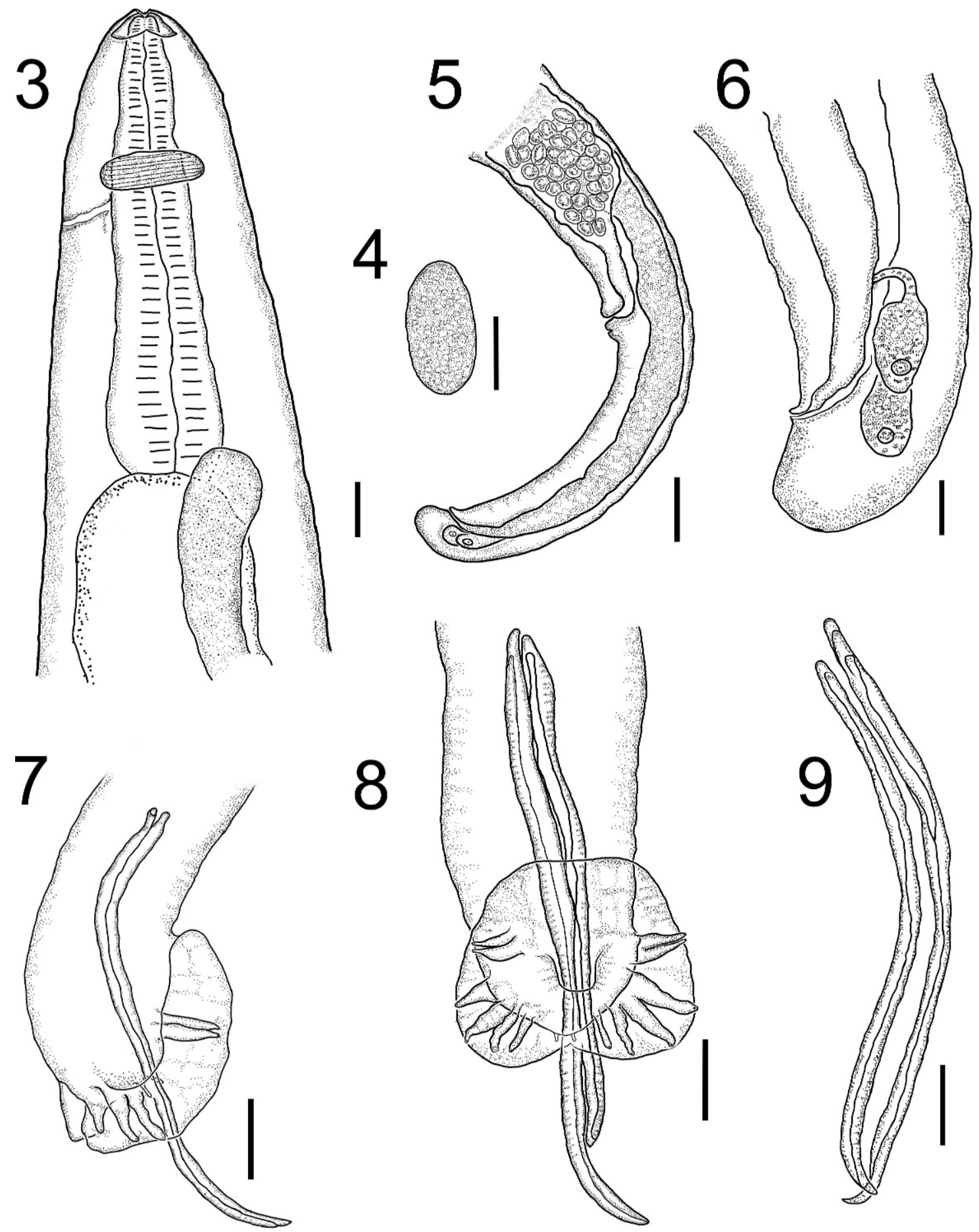

Figures 3-9. Akodonema luzsarmientae n.g. n. sp., (3) anterior end of gravid female from A. mollis Thomas, 1894, ventral view. (4) Egg of $A$. luzsarmientae n.g. n. sp. (5) Magnified posterior extremity of $A$. luzsarmientae n.g. n. sp., showing anus and glands associated with rectum. (6) Posterior extremity of gravid female of $A$. luzsarmientae n.g. n. sp. showing the vulva, vagina and eggs in the uterus. (7) Posterior extremity of a male of $A$. luzsarmientae n.g. n. sp., lateral view. (8) Posterior extremity of a male of $A$. luzsarmientae n.g. n. sp., ventral view. (9) Ventral view of spicules of $A$. luzsarmientae n.g. n. sp. Scale bars $=20 \mu \mathrm{m}$ (Figs. 3, 5); $100 \mu \mathrm{m}$ (Figs. 4, 6); $40 \mu \mathrm{m}$ (Figs. 7-9).

\section{Remarks}

Included in this family are Angiostrongylus Kaminski, 1905, Didelphostrongylus Prestwood, 1976, Filostrongylus Mackerras, 1955, Gurtlia Wolffhugel, 1933, Heterostrongylus Travassos, 1925, Madangiostrongylus Chabaud and Brygo, 1960, Parastrongylus Baylis, 1928, Pulmostrongylus Hsu, 1935, Rodentocaulus Schulz, Orlov and Kutass, 1939, Sobolevingylus
Romanov, 1952, Stefanskostrongylus Drozdz, 1970, and Tribostrongylus Anderson, 1963. A key for these genera is provided by Anderson (1978).

A second group of genera split into several species generally displays a dorsal ray modified from a single intact structure to a pair of divided papillae or papillae-like structures. This group of nematodes will need revision, preferably after an adequate phylogenetic analysis is conducted of the group. 


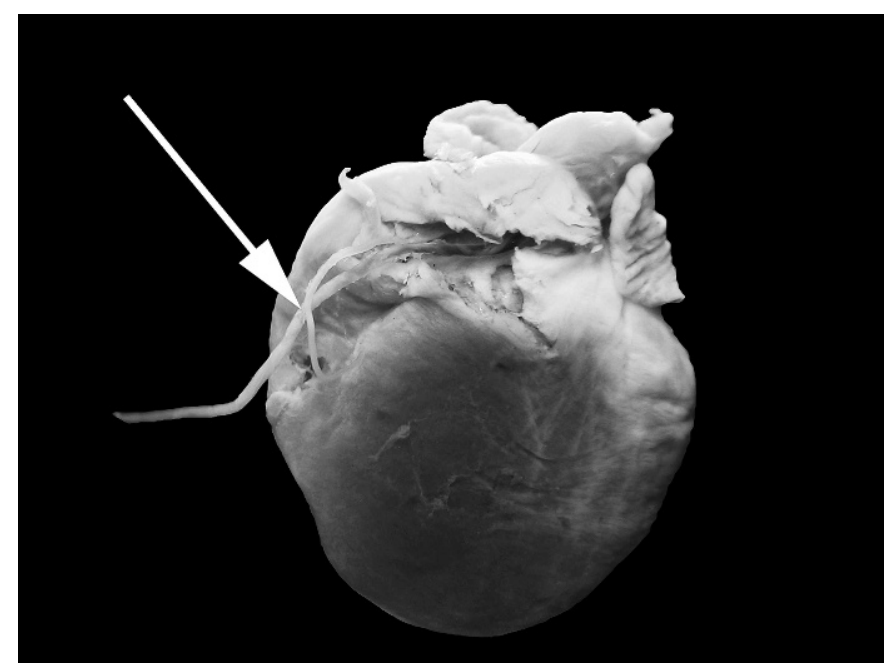

Figure 10. Akodonema luzsarmientae n.g. n.sp. in the heart of its host. Arrow shows a female worm in the heart of A. mollis Thomas, 1894, original magnification $(25 \times)$.

Genera included in this group include Akodonema n. gen., Aelurostrongylus Cameron, 1927, Andersostrongylus Webster, 1978, Antechinostrongylus Spratt, 1981, Madafilaroides Chabaud and Brygoo, 1960, Gallegostrongylus Mas-Coma, 1977, Marsupostrongylus Mackerras and Sandars, 1953, and Thaistrongylus Ohbayashi, Kamiya, and Bhaibulaya, 1979

This group can be distinguished from the Angiostrongylidae mainly by the characters of the bursa that show a gradual reduction, as discussed by Webster (1978). This group shows relationships to nematodes belonging to the Filarioidea in which the caudal region of the males possesses remnants of ventral and lateral rays.

\section{DISCUSSION}

To date, only 2 species of angiostrongylid-types of nematodes have been reported from mammals in Peru. They are Angiostrongylus costaricensis Morera and Céspedes, 1971, in the mesenteric vessels of "pichico barba blanca," Saguinus mystax (the tamarin), from Iquitos (Loreto), and Parastrongylus sp. in the pulmonary vein of "the painted big-eared mouse," Auliscomys pictus, from Casapalca (Lima) (Sarmiento et al., 1999). Until recently, just 2 previously reports of angiostrongylids in rodents from South America were known: Angiostrongylus lenzii in Akodon montensis Thomas, 1913, from Rio de Janeiro, Brazil (Souza et al., 2009), and Angiostrongylus morerai in Akodon azarae (Fischer, 1829) from Buenos Aires, Argentina (Robles et al., 2008); both nematodes were found in the pulmonary arteries of their rodent hosts.

Akodon is one of the most diverse genera of rodents in Peru, with 13 species recognized to date and many others yet to be described (Pacheco et al., 2009). The helminth fauna of $A$. mollis from Peru is apparently diverse, and the finding of $A$. luzsarmientae n.g. n. sp. could be corroborating the fact of the positive coevolutionary correlation between species richness and altitude (M. Morales, pers. obs.); however, further studies are necessary to test this hypothesis.

It is possible that $A$. luzsarmientae may be a cause of mortality in populations of $A$. mollis in the Andes, because this parasite may provoke inflammation of the lung and heart vessels, interfering with the normal function of these vital organs (Figs. 10-11), as

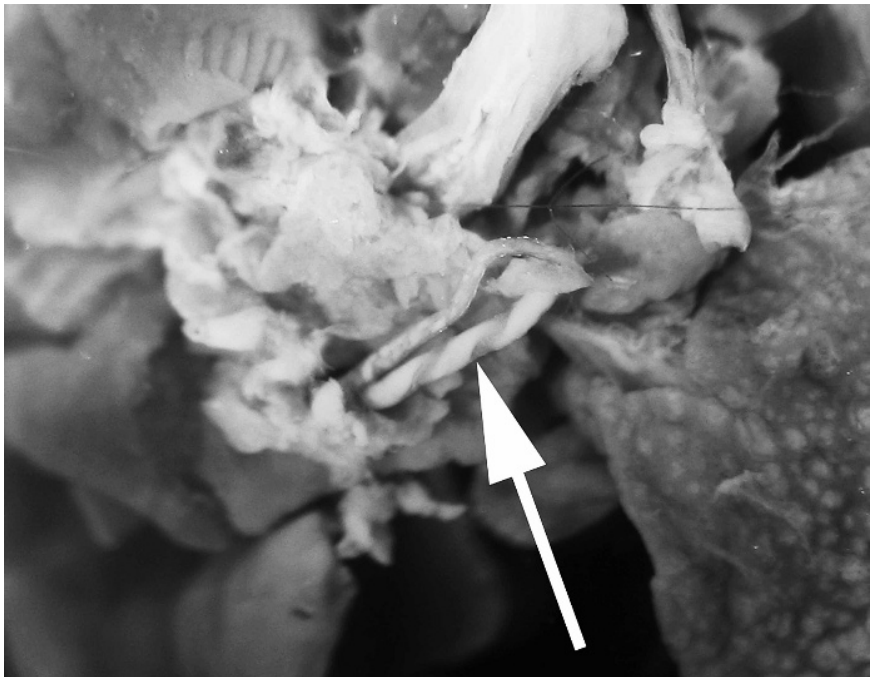

FIgURE 11. Akodonema luzsarmientae n.g. n.sp. in the lungs of $A$. mollis Thomas, 1894, original magnification $(20 \times)$.

has been shown with $A$. morerai in populations of $A$. azarae from Argentina (Robles et al., 2008). However, further studies are needed to demonstrate if these infections are fatal; some experimental infections with Angiostrongylus schmidti were not fatal to larger hosts such as cotton rats and white rats, but they were fatal to rodents with smaller body size (Kinsella, 1987). The present study constitutes a third report of an angiostrongylid-type parasite of a small mammal in Peru and extends the host and geographical distribution of this nematode to the Peruvian Andes in South America.

\section{ACKNOWLEDGMENTS}

We thank Dr. Alejandro Llanos and Abraham Cáceres for the opportunity to examine the rodents at the Museo de Historia Natural, MUSM. Special thanks are also due to Dr. Ben Nelson, New Mexico Highlands University, Las Vegas, New Mexico, for continued support in his laboratory by providing working space to the first author. Thanks to Professor R. Severino, of the Laboratorio de Zoología de Invertebrados of the Facultad de Ciencias Biológicas of the Universidad Nacional Mayor de San Marcos (MUSM), Lima, Peru, for his continued encouragement and valuable help with laboratory resources. Special thanks to Elena Vivar of the Department of Mammalogy of MUSM for corroborating the identification of the rodents and providing information of the host. Furthermore, thanks to Dr. Victor Pacheco for his help with the Akodon's picture and references. Thanks are due to Leonardo Romero of the Faculty of Biological Science of MUSM for his technical assistance with the photographs and Dr. Diana Silva from MUSM for his comments on the manuscript. Support was also provided by the J. Teague Self Endowment Fund for visiting scholars in the Harold W. Manter Laboratory of Parasitology, University of Nebraska-Lincoln, Lincoln, Nebraska.

\section{LITERATURE CITED}

Anderson, R. C. 1978. Key to genera of the superfamily Metastrongyloidea. No. 5. In Keys to the nematode parasites of vertebrates, R. C. Anderson, A. G. Chabaud, and S. Wilmot (eds). Commwealth Agricultural Bureaux. Farnham Royal, U.K., p. 1-40.

EisenberG, J. F. 1989. Mammals of the Neotropics. The northern Neotropics. Vol. I. Panama, Colombia, Venezuela, Guyana, Suriname, French Guiana. University of Chicago Press, Chicago, Illinois, $449 \mathrm{p}$.

Kinsella, J. M. 1987. Studies on the life cycle and host specificity of Parastrongylus schmidti (Nematoda: Angiostrongylidae). Proceedings of the Helminthological Society of Washington 54: 245-248. 
Mas-Coma, S. 1977. Gallegostrongylus ibicensis n. gen., n. sp. (Nematoda: Metastrongylidae), parasite pulmonaire de Mus musculus Linnaeus, 1758 (Rodentia: Muridae) a Ibiza (Baleares). Annales de Parasitologie Humaine et Comparée 52: 637-642.

Ohbayashi, M., M. Kamiya, And M. Bhaibulaya. 1979. Studies on the parasite fauna of Thailand 1. Two new metastrongylid nematodes, Angiostrongylus siamensis sp. n. and Thaistrongylus harinasutai gen. et sp. n. (Metastrongyloidea; Angiostrongylidae) from wild rats Japanese Journal of Veterinary Research 27: 5-10.

Pacheco, V. R., R. Cadenillas, E. Salas, C. Tello, and H. Zeballos. 2009. Diversidad y endemismo de los mamíferos del Perú. Revista Peruana de Biología 16: 5-32.

Patterson, B. D., M. H. Gallardo, and K. E. Freas. 1984. Systematic of mice of the subgenus Akodon (Rodentia: Cricetidae) in southern South America. Fieldiana, Zoology, new ser. 23: 1-16.

Patton, J. L., And M. F. Smith. 1992. Evolution and systematics of akodontine rodents (Muridae: Sigmodontinae) of Peru, with emphasis on the genus Akodon. Memorias del Museo de Historia Natural, Universidad Nacional Mayor de San Marcos, Lima 21: 83-103.

Robles, M. Del R., G. T. Navone, and M. Kinsella. 2008. A new Angiostrongylid (Nematode) species from the pulmonary arteries of
Akodon azarae (Rodentia: Cricetidae) in Argentina. Journal of Parasitology 94: 515-519.

Sarmiento, L., M. Tantaleán, And A. Huiza. 1999. Nemátodos parásitos del hombre y de los animales en el Perú. Revista Peruana de Parasitología 14: 9-65

Souza, J., R. O. Simões, S. A. R. C. Thiengo, W. S. Lima, E. M. Mota, R. Rodriguez-Silva, R. M. Lanfredi, And A. Maldonado, Jr. 2009. A new Metastrongylidae species (Nematoda: Metastrongylidae): A lungworm from Akodon montensis (Rodentia: Sigmodontinae) in Brazil. Journal of Parasitology 95: 1507-1511.

Spratt, D. M. 1961. Antechinostrongylus disgubernaculus gen. et sp. (Nematoda: Angiostrongylidae) from the marsupial mouse Antechinus swainsonii (Marsupialia: dasyuridae). Journal of Parasitology 67: 90-93

Ubelaker, J. E. 1986. Systematics of species referred to the genus Angiostrongylus. Journal of Parasitology 72: 237-244.

Webster, W. A. 1978. Andersostrongylus captivensis gen. et sp. n. (Metastrongyloidea: Filaroididae) from the lungs of the striped shunk, Mephitis mephitis. Journal of Parasitology 64: 459-462.

Wilson, D. E., AND D. M. ReEDER. 2005. Mammal species of the world. A taxonomic and geographic reference. Johns Hopkins University Press, Baltimore, Maryland. 2,142 p. 